\title{
Surface active properties and biological activity of novel nonionic surfactants containing pyrimidines and related nitrogen heterocyclic ring systems
}

\author{
By R. El-Sayed
}

\author{
Chemistry Department, Faculty of Science, Benha University, Egypt.
}

E-mail: ref_at@ hotmail.com

\section{RESUMEN}

\begin{abstract}
Propiedades tensoactivas y actividad biológica de nuevos surfactantes no iónicos conteniendo pirimidinas y anillos nitrogenados relacionados.
\end{abstract}

Una serie de derivados pirimidínicos y relacionados han sido preparados vía diferentes reacciones de formación de heterociclos entre 6-(4-octadeciloxifenil)-4-oxo-2-tioxo1,2,3,4-tetrahidropirimidina-5-carbonitrilo (4) y diferentes electrófilos y nucleófilos. Estos heterociclos tienen un átomo de hidrógeno activo $(\mathrm{NH}, \mathrm{OH}, \mathrm{o} \mathrm{COOH})$ que fue propoxilado con diferentes moles de óxido de propileno $(5,10$, o 15) para producir surfactantes no iónicos con una cadena alquílica larga y peso molecular apropiado para convertirse en una molécula anfifílica con un balance hidrofílico-lipofílico correcto que aumenta la solubilidad y la biodedradabilidad, decrece la toxicidad a los seres humanos, y se convierte en respetuoso con el medio ambiente. Además, las actividades antimicrobianas de estos compuestos fueron determinadas y se encontró que algunos de estos compuestos tuvieron una actividad similar o más alta que antibióticos comerciales (sulfadiazina), lo que los hace apropiados para aplicaciones diversas como la manufactura de medicamentos, pesticidas, emulsificantes, cosméticos, etc.

PALABRAS-CLAVE: Síntesis - Propiedades tensoactivas - Actividad antimicrobiana

\section{SUMMARY}

Surface active properties and biological activity of novel nonionic surfactants containing pyrimidines and related nitrogen heterocyclic ring systems.

A series of annelated pyrimidine derivatives has been synthesized via different heterocyclization reactions of suitably functionalized 6-(4-octadecyloxyphenyl)-4-oxo-2thioxo-1,2,3,4-tetrahydropyrimidine-5-carbonitrile (4) with different electrophiles and nucleophiles. These heterocycles bear an active hydrogen atom $(\mathrm{NH}, \mathrm{OH}$ or $\mathrm{COOH})$ which could be propoxylated using propylene oxide with different moles, 5, 10 and 15, to produce nonionic surfactant having a long alkyl chain with molecular weight suitable for becoming an amphiphilic molecule with correct hydrophilic-lypophilic balance which enhances solubility, biodegradability and hence lowers the toxicity to human beings and becomes environmentally friendly. In addition, the antimicrobial activities of these compounds were screened and it was found that some of these compounds have similar or higher activity compared with commercial antibiotic drugs (sulphadiazine), which make them suitable for diverse applications like the manufacturing of drugs, pesticides, emulsifiers, cosmetics, etc.

KEY-WORDS: Antimicrobial activity - Surface activity Synthesis.

\section{INTRODUCTION}

In continuation of our syntheses of surface active agents containing a heterocyclic moiety (Amin et al., 2004; El-Sayed et al., 2005a; Amin et al., 2006; Eissa and El-Sayed, 2006; El-Sayed, 2006), it was interesting to prepare some biologically active heterocycles which constitute an important class of organic compounds with diverse biological activities. Numerous fatty alcohols are now more available in their pure form and inexpensive enough to provide the chemical field with a wealth of reactions in which fatty alcohols are used as raw material in a variety of industrial products like pharmaceuticals, cosmetics, surfactants, paints, $\ldots$ etc. Pyrimidine nucleus is considered one of the most important classes of chemotherapeutic drugs especially among those which are used in large scale for the treatment of cancer and tumors (Xu et al., 2004), antiviral (Eman and Mohamed, 2004), antihistaminic (Maisa et al., 2004), analgesic activities (Aly and Nassar, 2004) and other pharmaceutical activities (Yvette and Aly, 2003)) in current medicinal use. In particular, our interest in developing an efficient syntheses of polyfunctionally substituted heterocycles using the readily obtainable pyrimidine as starting material from fatty alcohols motivated us to explore their potential use for the synthesis of polyfunctionally substituted pyrimidine derivatives useful for optimization of their biological activity. This encouraged us to continue our progress in applying octadecanol as starting material for synthesizing some new biologically active pyrimidine and fused pyrimidine derivatives. These compounds fulfill the following two requirements. First, an amphiphilic molecule must contain both a hydrophobic and a hydrophilic part. Second, the resence of active $\mathrm{H}$ atoms, $(\mathrm{NH}, \mathrm{SH}, \mathrm{OH}$ and $\mathrm{COOH})$ in the molecule which make the propyloxylation possible leading to the hydrophobic part in a desired hydrophilichydrophobic balance (Chaudlhuri et al., 1987). 


\section{MATERIALS AND METHODS}

Melting points are uncorrected. IR spectra in $\mathrm{KBr}$ were measured on a Pye-Uncam SP-1000 infrared spectrophotometer on a $\mathrm{KBr}$ disk or nujol. The ${ }^{1}$ HNMR spectra were obtained on a Varian EM-390$60 \mathrm{MHz}$ spectrometer in $\left(\mathrm{D}_{6}\right)$ DMSO as the solvent, tetramethylsilane (TMS) served as an internal reference and chemical shifts are expressed as $\delta$ (ppm). Microanalyses were preformed by the Micro analytical Unit at Cairo University. Antimicrobial and antifungal activity tests were carried out by the microbiology laboratory, Faculty of Science, Benha University, Egypt.

\subsection{Chemical synthesis of heterocyclic derivatives}

\subsubsection{Synthesis of chlorooctadecane (2)}

A mixture of octadecanol 1 (0.0095 mol), $\mathrm{POCl}_{3}$ $(0.29 \mathrm{~mol})$ and $\mathrm{PCl}_{5}(0.015 \mathrm{~mol})$ was heated to reflux on a water bath for $4 \mathrm{~h}$ (Aly 2005). The mixture was poured gradually onto crushed ice and the separated product was filtered off and crystallized from benzene to give 2. Yield (1.52 g, 70\%, yellow oil).

\subsubsection{Synthesis of 4-octadecyloxybenzaldehyde (3)}

Compound 2 (10 mmol) was added to a mixture of 4-hydroxybenzaldehyde (1.22 g, $10 \mathrm{mmol})$ and anhydrous $\mathrm{K}_{2} \mathrm{CO}_{3}(2.90 \mathrm{~g}, 30 \mathrm{mmol})$ in dry acetone $(50 \mathrm{ml})$. The mixture was heated to reflux on a water bath for 5-6 h, poured into ice-cold $\mathrm{H}_{2} \mathrm{O}$ and then extracted with $\mathrm{Et}_{2} \mathrm{O}$. The $\mathrm{Et}_{2} \mathrm{O}$ layer was dried (anh $\mathrm{Na}_{2} \mathrm{SO}_{4}$ ) and the solvent evaporated to give 3. Yield (1.52g, $76 \%$ pale yellow solid), M.p. $126-28^{\circ}$. IR: 2913 and 2850 ( $\mathrm{CH}$ aliphatic), $1695(\mathrm{C}=\mathrm{O}), 820$ and 690 (C-O). ${ }^{1} \mathrm{HNMR}\left(\mathrm{CDCl}_{3}\right): 0.96(t, 3 \mathrm{H}, \mathrm{Me}), 1.22$ $1.35\left(m, 32 \mathrm{H}, 16 \mathrm{CH}_{2}\right), 3.72\left(t, 2 \mathrm{H}, \mathrm{CH}_{2}-\mathrm{O}\right), 9.71(s$, $1 \mathrm{H}, \mathrm{CHO})$ and 6.90-7.77 (m, 4H, ArH). Anal. calc for $\mathrm{C}_{25} \mathrm{H}_{42} \mathrm{O}_{2}$ (374.61): C 80.16, $\mathrm{H}$ 11.30, found: $\mathrm{C}$ 80.20, H $11.32 \%$.

\subsubsection{Synthesis of 6-(4-octadecyloxyphenyl)-4- oxo-2-thioxo-1,2,3,4-tetrahydropyrimidine-5- carbonitrile (4)}

A mixture of 4-octadecyloxybenzaldehyde (3) $(0.01 \mathrm{~mol})$, ethyl cyanoacetate $(0.01 \mathrm{~mol})$, thiourea $(0.01 \mathrm{~mol})$ and $\mathrm{K}_{2} \mathrm{CO}_{3}(0.01 \mathrm{~mol})$ in $\mathrm{EtOH}(40 \mathrm{ml})$ was heated to reflux for $24 \mathrm{~h}$. The precipitate formed after cooling and acidification was filtered off and crystallized from DMF/ $\mathrm{H}_{2} \mathrm{O}$ to give 4 . Yield $(0.82 \mathrm{~g}$, $52 \%$ red brown crystals), M.p. 118-20․ IR: $3220-$ $3180(\mathrm{NH}), 2950-2820$ ( $\mathrm{CH}$ aliphatic), $2225(\mathrm{C} \equiv \mathrm{N})$, 1675 (CO), 1600 (C=N), 1260 (CS). ${ }^{1} \mathrm{HNMR}$ (DMSO) $\delta: 0.90(t, 3 \mathrm{H}, \mathrm{Me}), 1.29-1.32(\mathrm{~m}, 32 \mathrm{H}$, $\left.16 \mathrm{CH}_{2}\right), 3.84\left(t, 2 \mathrm{H}, \mathrm{CH}_{2}-\mathrm{O}\right), 6.70-7.76(m, 4 \mathrm{H}, \mathrm{ArH})$ and 8.22 (brs, $2 \mathrm{H}, 2 \mathrm{NH})$. Anal. calc for $\mathrm{C}_{29} \mathrm{H}_{43} \mathrm{~N}_{3} \mathrm{O}_{2} \mathrm{~S}$ (497.75): C 69.98, H 8.71, N 8.44, S 6.44, found: C 69.95, H 8.72, N 8.47, S $6.49 \%$.

\subsubsection{Synthesis of 4-hydroxy-2-methylsulfanyl-6- (4-octadecyloxyphenyl)pyrimidine-5- carbonitrile (5)}

A solution of $4(0.01 \mathrm{~mol})$ and $\mathrm{Mel}(0.01 \mathrm{~mol})$ in EtONa (prepared by dissolving $1.0 \mathrm{~g}$ of $\mathrm{Na}$ in $50 \mathrm{ml}$ of $\mathrm{EtOH}$ ) was heated to reflux for $5 \mathrm{~h}$. The mixture was then cooled and poured onto ice-cold $\mathrm{H}_{2} \mathrm{O}$. The solid product obtained after acidification with $\mathrm{HCl}$ was filtered off, washed with water and crystallized from EtOH to give 5. Yield (1.72 g, 85\% brown solid), M.p. 186-88 . IR: $3420(\mathrm{OH}), 2920-2850(\mathrm{CH}$ aliphatic), $2218(\mathrm{C} \equiv \mathrm{N}), 1598(\mathrm{C}=\mathrm{N}) .{ }^{1} \mathrm{HNMR}$ $\left(\mathrm{CDCl}_{3}\right): 0.95(t, 3 \mathrm{H}, \mathrm{Me}), 1.29-1.62\left(m, 32 \mathrm{H}, 16 \mathrm{CH}_{2}\right)$ $2.53\left(s, 3 \mathrm{H}, \mathrm{SCH}_{3}\right), 3.94\left(t, 2 \mathrm{H}, \mathrm{CH}_{2}-\mathrm{O}\right), 5.01(s, 1 \mathrm{H}$, $\mathrm{OH})$ and 7.42-8.76 $(\mathrm{m}, 4 \mathrm{H}, \mathrm{ArH})$. Anal. calc for $\mathrm{C}_{30} \mathrm{H}_{45} \mathrm{~N}_{3} \mathrm{O}_{2} \mathrm{~S}$ (511.78): C 70.41, $\mathrm{H}$ 8.86, N 8.21, $\mathrm{S}$ 6.27,found: C 70.40, H 8.82, N 8.26, S $6.31 \%$.

\subsubsection{Synthesis of 4-chloro-2-methylsulfanyl-6- (4-octadecyloxyphenyl)-pyrimidine-5- carbonitrile (6)}

A mixture of 5 (0.0095 mol), $\mathrm{POCl}_{3}(0.29 \mathrm{~mol})$ and $\mathrm{PCl}_{5}(0.015 \mathrm{~mol})$ was heated to reflux on a water bath for $4 \mathrm{~h}$. The mixture was poured gradually onto crushed ice and the solid separated was filtered off and crystallized from benzene to give 6 . Yield (1.32 g, 71\% pale yellow crystal), M.p. 167-69 . IR: 2915 and 2851 (CH aliphatic), 2220 $(\mathrm{C} \equiv \mathrm{N}), 1610(\mathrm{C}=\mathrm{N}) .{ }^{1} \mathrm{HNMR}\left(\mathrm{CDCl}_{3}\right): 0.85(t, 3 \mathrm{H}$, $\mathrm{Me})$, 1.25-1.52 (m, 32H, 16CH $\mathrm{CH}_{2} 2.48\left(\mathrm{~s}, 3 \mathrm{H}, \mathrm{SCH}_{3}\right)$, $3.76\left(t, 2 \mathrm{H}, \mathrm{CH}_{2}-\mathrm{O}\right)$ and 6.64-7.59 ( $\left.m, 4 \mathrm{H}, \mathrm{ArH}\right)$. Anal. calc for $\mathrm{C}_{30} \mathrm{H}_{44} \mathrm{CIN}_{3} \mathrm{OS}$ (530.22): C 67.96, $\mathrm{H}$ 8.36, N 7.93, Cl 6.69, S 6.05,found: C 67.95, H 8.33, N 7.97, Cl 6.70, S 6.07\%.

\subsubsection{Synthesis of 2,4-dihydrazino-6-(4- octadecyloxyphenyl)-pyrimidine-5- carbonitrile (7)}

A mixture of $6(0.06 \mathrm{~mol})$ and hydrazine hydrate $(2.3 \mathrm{ml})$ in $\mathrm{BuOH}$ was heated to reflux for $2 \mathrm{~h}$. The resulting solid was collected by filtration and crystallized from $\mathrm{BuOH}$ to give 7 . Yield $(1.55 \mathrm{~g}, 78 \%$ red brown), M.p. 192-93. IR: 3320-3180 $\left(\mathrm{NHNH}_{2}\right)$, 2920 and 2847 ( $\mathrm{CH}$ aliphatic), 2228 (C?N), 1605 $(\mathrm{C}=\mathrm{N}) .{ }^{1} \mathrm{HNMR}\left(\mathrm{CDCl}_{3}\right): 0.96(t, 3 \mathrm{H}, \mathrm{Me}), 1.29-1.32$ $\left(m, 32 \mathrm{H}, 16 \mathrm{CH}_{2}\right), 3.95\left(t, 2 \mathrm{H}, \mathrm{CH}_{2}-\mathrm{O}\right), 4.91,4.96$ (brs, 4H, 2 $\left.\mathrm{NH}_{2}\right), 6.92-7.78(m, 4 \mathrm{H}, \mathrm{ArH})$ and 8.11, $8.13(2 \mathrm{~s}, 2 \mathrm{H}, 2 \mathrm{NH})$. Anal. calc for $\mathrm{C}_{29} \mathrm{H}_{47} \mathrm{~N}_{7} \mathrm{O}$ (509.38): C 68.33, H 9.29, N 19.24, found: C 68.29, H 9.29, N 19.22\%.

\subsubsection{Synthesis of 6-hydrazino-4-(4- octadecyloxyphenyl)-1H-pyrazolo [3,4-d] pyrimidin-3-ylamine (8)}

A solution of $7(0.001 \mathrm{~mol})$ in $\mathrm{BuOH}(20 \mathrm{ml})$ was heated to reflux for $5 \mathrm{~h}$. The solvent was removed at reduced pressure and the residue crystallized from $\mathrm{BuOH}$ to give 8 . Yield (1.87g, $88 \%$ yellow crystals), 
M.p. $178-80^{\circ}$. IR: $3340-3200\left(\mathrm{NH}_{2}\right.$ and $\left.\mathrm{NHNH}_{2}\right)$, 2913 and 2850 (CH aliphatic), $1598(\mathrm{C}=\mathrm{N}) .{ }^{1} \mathrm{H}$ NMR (DMSO): $0.96(t, 3 \mathrm{H}, \mathrm{Me}), 1.24-1.62(m, 32 \mathrm{H}$, $\left.16 \mathrm{CH}_{2}\right), 3.65\left(t, 2 \mathrm{H}, \mathrm{CH}_{2}-\mathrm{O}\right), 4.38$ (brs, $2 \mathrm{H}, \mathrm{NH}_{2}$ ), 5.22 (brs, $\left.2 \mathrm{H}, \mathrm{NH}_{2}\right), 7.43-7.96(m, 4 \mathrm{H}, \mathrm{ArH})$ and 8.12, $8.35(2 \mathrm{~s}, 2 \mathrm{H}, 2 \mathrm{NH})$. Anal. calc for $\mathrm{C}_{29} \mathrm{H}_{47} \mathrm{~N}_{7} \mathrm{O}$ (509.74): C 68.33, H 9.29, N 19.24,found: C 68.30, H 9.25, N 19.20\%.

\subsubsection{Synthesis of 4-mercapto-2-methylsulfanyl-6- (4-octadecyloxyphenyl)-pyrimidine-5- carbonitrile (9)}

To a solution of $6(0.01 \mathrm{~mol})$ in $\mathrm{EtOH}(20 \mathrm{ml})$, thiourea $(0.01 \mathrm{~mol})$ was added and the reaction mixture was heated under reflux for $10 \mathrm{~h}$. The solid obtained after cooling was crystallized from $\mathrm{EtOH}$ to give 9. Yield (1.82g, 81\% white yellow solid), M.p. 156-58. IR: 2918 and 2845 (CH aliphatic), 2330 (SH), $2227(\mathrm{C} \equiv \mathrm{N}), 1600(\mathrm{C}=\mathrm{N}) .{ }^{1} \mathrm{HNMR}\left(\mathrm{CDCl}_{3}\right)$ : $0.90(t, 3 \mathrm{H}, \mathrm{Me}), 1.28-1.60\left(m, 32 \mathrm{H}, 16 \mathrm{CH}_{2}\right), 2.48$ $\left(s, 3 \mathrm{H}, \mathrm{SCH}_{3}\right), 3.53(s, 1 \mathrm{H}, \mathrm{SH}), 3.94\left(t, 2 \mathrm{H}, \mathrm{CH}_{2}-\mathrm{O}\right)$ and 6.64-7.46 $(\mathrm{m}, 4 \mathrm{H}, \mathrm{ArH})$. Anal.calc for $\mathrm{C}_{30} \mathrm{H}_{45} \mathrm{~N}_{3} \mathrm{~S}_{2} \mathrm{O}$ (527.84): C68.26, H 8.59, N 7.96, S 7.95; found: C 68.30, H 8.62, N 7.95, S 7.99\%.

\subsubsection{Synthesis of [5-cyano-2-methylsulfanyl-6-(4- octadecyloxyphenyl)-pyrimidin-4-ylsulfanyl]- acetic acid (10)}

A mixture of $9(0.001 \mathrm{~mol}), \mathrm{AcONa}(0.003 \mathrm{~mol})$ and chloroacetic acid $(0.001 \mathrm{~mol})$ in $\mathrm{EtOH}(30 \mathrm{ml})$ was heated under reflux for $3 \mathrm{~h}$. The precipitate formed after cooling was filtered and crystallized from benzene to yield 10 . Yield $(1.22 \mathrm{~g}, 68 \%$ yellow crystals), M.p. 195-96 ${ }^{\circ}$ IR: 2921 and $2851(\mathrm{CH}$ aliphatic), $2218(\mathrm{C} \equiv \mathrm{N}), 1720(\mathrm{CO}), 1610(\mathrm{C}=\mathrm{N})$. ${ }^{1} \mathrm{HNMR}$ (DMSO): 0.95 ( $\left.t, 3 \mathrm{H}, \mathrm{Me}\right), 1.29-1.62(\mathrm{~m}$, $\left.32 \mathrm{H}, 16 \mathrm{CH}_{2}\right), 2.49\left(s, 3 \mathrm{H}, \mathrm{SCH}_{3}\right), 3.90\left(t, 2 \mathrm{H}, \mathrm{CH}_{2}\right.$ O), $3.85\left(s, 2 \mathrm{H}, \mathrm{SCH}_{2}\right), 6.91-7.76(m, 4 \mathrm{H}, \mathrm{ArH})$ and $11.01(s, 1 \mathrm{H}, \mathrm{OH})$. Anal. calc for $\mathrm{C}_{32} \mathrm{H}_{47} \mathrm{~N}_{3} \mathrm{O}_{3} \mathrm{~S}_{2}$ (585.88): C 65.60, H 8.09, N 7.17, S 10.95, found C 65.62, H 8.11, N 7.20, S 10.98, \%.

\subsubsection{Synthesis of 5-amino-2-methylsulfanyl-4- (4-octadecyloxyphenyl)-thieno[2,3- d]pyrimidine-6-carboxylic acid (11)}

To a solution of $10(0.01 \mathrm{~mol})$ in $\mathrm{EtOH}(20 \mathrm{ml})$, EtONa (50 mg Na in $25 \mathrm{ml} \mathrm{EtOH}$ ) was added by droplets and the mixture was heated under reflux for $30 \mathrm{~min}$. The solid that formed while hot was collected and crystallized from EtOH to give 11. Yield (1.72g, 83\% brown solid), M.p. 182-84. IR: $3325,3310\left(\mathrm{NH}_{2}\right), 2918$ and $2848(\mathrm{CH}$ aliphatic), $1725(\mathrm{CO}), 1610(\mathrm{C}=\mathrm{N}) .{ }^{1} \mathrm{H}$ NMR $\left(\mathrm{CDCl}_{3}\right): 0.95(t$, $3 \mathrm{H}, \mathrm{Me}), 1.22-1.60\left(\mathrm{~m}, 32 \mathrm{H}, 16 \mathrm{CH}_{2}\right), 2.50(\mathrm{~s}, 3 \mathrm{H}$, $\left.\mathrm{SCH}_{3}\right), 3.84\left(t, 2 \mathrm{H}, \mathrm{CH}_{2}-\mathrm{O}\right), 7.73-8.67(m, 4 \mathrm{H}, \mathrm{ArH})$ and 4.80 (brs, $2 \mathrm{H}, \mathrm{NH}_{2}$ ). Anal. calc for $\mathrm{C}_{32} \mathrm{H}_{47} \mathrm{~N}_{3} \mathrm{O}_{3} \mathrm{~S}_{2}$ (585.88): C 65.60, H 8.09, N 7.17, S 10.95, found C 65.65, H 8.13 , N 7.15, S $10.99 \%$.

\subsubsection{Synthesis of 2-methylsulfanyl-4-(4- octadecyloxyphenyl)-7-phenyl-6-thioxo-6,7- dihydro-5H-9-thia-1,3,5,7-tetraaza-fluoren- 8-one (12)}

To a solution of $11(0.001 \mathrm{~mol})$ in pyridine $(25 \mathrm{ml})$, phenyl isothiocyanate $(0.001 \mathrm{~mol})$ was added and the reaction mixture was refluxed in an oil bath for 20 $\mathrm{h}$. The mixture after cooling was poured into ice $/ \mathrm{HCl}$ and the solid separated was filtered, washed with cold $\mathrm{EtOH}$, dried and crystallized from EtOH/DMF to give 12. Yield (1.05g, 59\% pale yellow solid), M.p. 236-38 . IR: $3240(\mathrm{NH}), 2913$ and $2850(\mathrm{CH}$ aliphatic), 1670 (CO), $1610(\mathrm{C}=\mathrm{N}), 1267(\mathrm{CS})$. ${ }^{1} \mathrm{HNMR}\left(\mathrm{CDCl}_{3}\right): 0.96(t, 3 \mathrm{H}, \mathrm{Me}), 1.29-1.62(\mathrm{~m}, 32 \mathrm{H}$, $\left.16 \mathrm{CH}_{2}\right), 2.48\left(s, 3 \mathrm{H}, \mathrm{SCH}_{3}\right), 3.90\left(t, 2 \mathrm{H}, \mathrm{CH}_{2}-\mathrm{O}\right)$, 6.62-7.77 (m, 9H, ArH); $8.01(s, 1 \mathrm{H}, \mathrm{NH})$. Anal. calc for $\mathrm{C}_{39} \mathrm{H}_{50} \mathrm{~N}_{4} \mathrm{O}_{2} \mathrm{~S}_{3}$ (703.05): C 66.63, $\mathrm{H} 7.17, \mathrm{~N} 7.97$, S 13.68, found: C 66.60, H 7.15, N 8.01, S 13.73\%.

\subsubsection{Synthesis of 4-(5-amino-[1,3,4]thiadiazol-2- yl)-2-methylsulfanyl-6-(4- octadecyloxyphenyl)-pyrimidine-5- carbonitrile (13)}

A mixture of $10(0.01 \mathrm{~mol})$ and thiosemicarbazide $(0.01 \mathrm{~mol})$ and $\mathrm{POCl}_{3}(0.01 \mathrm{~mol})$ was warmed at $60^{\circ}$ for $1 \mathrm{~h}$ and the temperature was raised to $90^{\circ}$ for an additional $2 \mathrm{~h}$. The contents were poured onto crushed ice, cooled to $10^{\circ}, \mathrm{pH}$ adjusted to 8-10 M $\mathrm{NaOH}$ and the resulting solid was crystallized from DMF to give 13; yield $(1.22 \mathrm{~g}, 70 \%$ red brown crystals), M.p. 146-48 . IR: $3240\left(\mathrm{NH}_{2}\right), 2918$ and $2852(\mathrm{CH}$ aliphatic), $2225(\mathrm{C} \equiv \mathrm{N})$ and $1590(\mathrm{C}=\mathrm{N})$. ${ }^{1} \mathrm{HNMR}\left(\mathrm{CDCl}_{3}\right): 0.80(t, 3 \mathrm{H}, \mathrm{Me}), 1.25-1.60(\mathrm{~m}, 30$ $\left.\mathrm{H}, 16 \mathrm{CH}_{2}\right), 2.47\left(s, 3 \mathrm{H}, \mathrm{SCH}_{3}\right), 3.45\left(s, 2 \mathrm{H}, \mathrm{NH}_{2}\right)$, $3.80\left(t, 2 \mathrm{H}, \mathrm{CH}_{2}-\mathrm{O}\right)$ and 6.90-7.72 (m, 4H, ArH). Anal. calc for $\mathrm{C}_{32} \mathrm{H}_{46} \mathrm{~N}_{6} \mathrm{OS}_{2}$ (594.89): $\mathrm{C}$ 64.61, $\mathrm{H}$ 7.79, N 14.13, S 10.78, found: C 64.65, H 7.77, N 14.18, S $10.81 \%$.

\subsubsection{Synthesis of 2-[5-cyano-2-methylsulfanyl-6- (4-octadecyloxyphenyl)-pyrimidin-4- ylsulfanyl]-4-oxo-4-phenyl-butyric acid (14)}

A solution of $9(0.002 \mathrm{~mol})$ and $\beta$-benzoylacrylic acid $(0.002 \mathrm{~mol})$ and a few drops of pyridine in dry benzene $(50 \mathrm{ml})$ was left at room temperature for 48 $\mathrm{h}$ (El-Sayed et al., 2005b). The mixture was concentrated under reduced pressure and the cold mixture was washed with light petroleum ether. The solid obtained was crystallized from benzene to give 14 ; yield $(1.72 \mathrm{~g}, 85 \%$ brown solid), M.p. 22628. IR: $3440(\mathrm{OH}), 2920,2851$ (CH aliphatic) and 1705, 1690 (CO of acid and ketone). ${ }^{1}$ HNMR $\left(\mathrm{CDCl}_{3}\right): 0.95(t, 3 \mathrm{H}, \mathrm{Me}), 1.29-1.62(\mathrm{~m}, 32 \mathrm{H}$, $\left.16 \mathrm{CH}_{2}\right), 2.47\left(s, 3 \mathrm{H}, \mathrm{SCH}_{3}\right), 3.92\left(t, 1 \mathrm{H}, \mathrm{CHCH}_{2}\right)$, $3.04,3.32\left(d, 2 \mathrm{H}, \mathrm{CHCH}_{2}\right), 3.94\left(t, 2 \mathrm{H}, \mathrm{CH}_{2}-\mathrm{O}\right)$, 7.35-7.91 (m, 9H, ArH) and $11.01(s, 1 \mathrm{H}, \mathrm{OH})$. Anal. calc for $\mathrm{C}_{40} \mathrm{H}_{53} \mathrm{~N}_{3} \mathrm{O}_{4} \mathrm{~S}_{2}$ (704.01): $\mathrm{C}$ 68.24, $\mathrm{H}$ 7.59, N 5.97, S 9.11, found: C 68.27, H 7.63, N 5.95, S $9.15 \%$ 


\subsubsection{Synthesis of 2-methylsulfanyl-4-(4- octadecyloxyphenyl)-6-(3-oxo-6-phenyl- 2,3,4,5-tetrahydropyridazin-4-ylsulfanyl)- pyrimidine-5-carbonitrile (15)}

A mixture of $14(0.01 \mathrm{~mol})$ and hydrazine hydrate $(0.01 \mathrm{~mol})$ in $\mathrm{EtOH}(40 \mathrm{ml})$ was heated under reflux for $5 \mathrm{~h}$, then the solution was concentrated. The product was obtained by filtration and crystallized from EtOH to give 15 . Yield $(1.65 \mathrm{~g}, 78 \%$ red brown solid), M.p. 190-92 . IR: $3370(\mathrm{NH}), 2919$ and 2850 ( $\mathrm{CH}$ aliphatic), $2220 \quad(\mathrm{C} \equiv \mathrm{N}), 1675 \quad(\mathrm{CO}$ of pyridazine), and $1590(\mathrm{C}=\mathrm{N}) .{ }^{1} \mathrm{HNMR}\left(\mathrm{CDCl}_{3}\right): 0.95$ $(t, 3 \mathrm{H}, \mathrm{Me}), 1.29-1.62\left(m, 32 \mathrm{H}, 16 \mathrm{CH}_{2}\right), 1.87,2.21$ (d, $2 \mathrm{H}, \mathrm{CHCH}_{2}$ of pyridazine ring), $2.47(s, 3 \mathrm{H}$, $\left.\mathrm{SCH}_{3}\right), 3.52\left(t, 1 \mathrm{H}, \mathrm{CHCH}_{2}\right.$ of pyridazine ring), 3.80 $\left(t, 2 \mathrm{H}, \mathrm{CH}_{2}-\mathrm{O}\right), 7.02(s, 1 \mathrm{H}, \mathrm{NH})$ and 7.30-7.71 $(\mathrm{m}$, $9 \mathrm{H}, \mathrm{ArH}$ ). Anal. calc for $\mathrm{C}_{40} \mathrm{H}_{53} \mathrm{~N}_{5} \mathrm{O}_{2} \mathrm{~S}_{2}$ (700.03): $\mathrm{C}$ 68.63, H 7.63, N 10.00, S 9.16, found C 68.62, H 7.60, N 10.06, S 9.19\%.

\subsubsection{Synthesis of 2-methylsulfanyl-4-(4- octadecyloxyphenyl)-6-(6-oxo-3-phenyl-5,6- dihydro-2H-[1,2]oxazin-5-ylsulfanyl)- pyrimidine-5-carbonitrile (16)}

A mixture of $14(0.01 \mathrm{~mol})$ and $\mathrm{NH}_{2} \mathrm{OH} / \mathrm{HCl}(0.01$ mol) in pyridine $(20 \mathrm{ml})$ and a few drops of $\mathrm{H}_{2} \mathrm{O}$ was heated under reflux for $12 \mathrm{~h}$. The mixture was poured onto ice-cold $\mathrm{HCl}$. The product was obtained by filtration and crystallized from EtOH to give 16 . Yield (1.43g, 65\% pale yellow crystals), M.p. 18587. . IR: 2919 and 2851 ( $\mathrm{CH}$ aliphatic), $2225(\mathrm{C} \equiv \mathrm{N})$ and 1680 attributed to carbonyl of cyclic ether. ${ }^{1} \mathrm{H}$ $\operatorname{NMR}\left(\mathrm{CDCl}_{3}\right): 0.96(t, 3 \mathrm{H}, \mathrm{Me}), 1.25-1.60(m, 32 \mathrm{H}$, $\left.16 \mathrm{CH}_{2}\right), 2.35,2.60\left(d, 2 \mathrm{H}, \mathrm{CHCH}_{2} \mathrm{CH}\right.$ of oxazin ring), $2.51\left(s, 3 \mathrm{H}, \mathrm{SCH}_{3}\right), 3.41\left(t, 1 \mathrm{H}, \mathrm{CHCH}_{2}\right.$ of oxazin ring), $3.81\left(t, 1 \mathrm{H}, \mathrm{CH}_{2} \mathrm{CH}\right.$ of oxazin ring), $8.01(s, 1$ $\mathrm{H}, \mathrm{NH})$ and 6.81-7.25 (m, 9H, ArH). Anal. calc for $\mathrm{C}_{40} \mathrm{H}_{52} \mathrm{~N}_{4} \mathrm{O}_{3} \mathrm{~S}_{2}$ (701.01): C 68.54, H 7.48, N 7.99, S 9.15, found C 68.58, H 7.50, N 7.96, S 9.17\%.

\subsection{Conversion of the prepared compounds to nonionic surfactants}

Nonionic surfactants are prepared by the addition of $n$ moles of propylene oxide $(n=5,10$, 15) to one mol of suitable product using $\mathrm{KOH}$ as catalyst. A complete description of the procedure is given in (Morgos et al., 1983a). The addition of propylene oxide gave a mixture of propenoxylated products whose structures were confirmed by IR and ${ }^{1} \mathrm{HNMR}$ spectra. IR spectra showed two broad bands at 1100 and $950 \mathrm{~cm}^{-1}$ characteristic for $\mathrm{vC}$ $\mathrm{O}-\mathrm{C}$ ether linkage of polypropenoxy chain and ${ }^{1} \mathrm{HNMR}$ spectra showed the protons of propenoxy groups $\delta=3.2-3.7\left(\mathrm{~m},-\mathrm{CH}_{2} \mathrm{CH}\left(\mathrm{CH}_{3}\right)-\mathrm{O}\right)$-.

\subsection{Determination of the performance properties}

2.3.1. Surface and interfacial tension were measured with a Du-Nouy tensiometer (Findly,
1963) (Kruss, Type 8451) using an aqueous solution of surfactants $(0.1 \mathrm{wt} \%)$ at room temperature $\left(25^{\circ} \mathrm{C}\right)$.

2.3.2. Cloud point was determined by gradually heating a surfactant solution (1.0 wt \%) in a bath of controlled temperature, and recording the temperature at which the clear, or nearly clear solutions become definitely turbid. The reproducibility of this temperature was checked by cooling the solutions until they become clear again (Wiel et al., 1963).

2.3.3. Wetting time was determined by immersing a sample of cotton fabric in $1.0 \mathrm{wt} \%$ aqueous solution of surfactants (Draves and Clarkso, 1931).

2.3.4. Foaming properties were measured according to (El-Sukkary et al., 1987). In this procedure a $25 \mathrm{ml}$ solution (1.0 wt \%) was shaken vigorously for 10 seconds in a $100 \mathrm{ml}$ graduated cylinder with a glass stopper at $25^{\circ}$. The solution was allowed to stand for 30 seconds and then the foam height was measured.

2.3.5. Emulsification stability was prepared from $10 \mathrm{ml}$ of a $20 \mathrm{mmol}$ aqueous solution of surfactant and $5 \mathrm{ml}$ of toluene at $40^{\circ}$. Emulsion stability was determined as the time which $9 \mathrm{ml}$ of aqueous layer took to separate from the emulsion counting since cession of shaking (Takeshi, 1970).

\subsection{Biodegradability}

Biodegradability was evaluated by surface tension measurements which were taken each day, on each sample during the degradation test. Biodegradation percent (D) (Eter et al., 1974) for each sample was calculated using the following equation: $\mathbf{D}=\left[\left(\gamma_{t}-\gamma_{0}\right) /\left(\gamma_{b t}-\gamma_{0}\right)\right] \times 100$, where $\gamma_{t}=$ surface tension at time $t, \gamma_{0}=$ surface tension at zero time, $\gamma_{b t}=$ surface tension of blank experiment at time $t$ (without sample).

\subsection{Biological activity}

The biological activities of these compounds have been evaluated by filter paper disc method (Rosen, 1989). After dissolving in N,N-dimethylformamide to obtain a $1 \mathrm{mg} / \mathrm{mL}$ solution (1000 ppm). The inhibition zones of incubation period of 3 days at $37^{\circ}$ for Echerichia coli and $28^{\circ}$ for other bacteria and fungi were recorded. N, N-Dimethylformamide alone showed no inhibition zone.

\section{RESULTS AND DISCUSSION}

\subsection{Synthesis}

The reaction of octadecanol (1) with $\mathrm{POCl}_{3} / \mathrm{PCl}_{5}$ gave 1-chlorooctadecane (2) (Wanchai Warinthorn, 
2006) which was heated to reflux with 4hydroxybenzaldehyde in dry acetone in the presence of anhydrous $\mathrm{K}_{2} \mathrm{CO}_{3}$ (Gean et al., 2001) to produce 4-octadecyloxybenzaldehyde (3). The latter was allowed to condense with ethyl cyanoacetate and thiourea to afford 6-(4-octadecyloxy-phenyl)-4-oxo-2thioxo-1,2,3,4-tetrahydropyrimidine-5-carbonitrile (4) according to Scheme 1.

Pyrimidine derivative 4 was used in the synthesis of alkylsulfanylpyrimidine derivatives that have recently been identified as highly specific reverse transcriptase inhibitors against human immunodeficiency virus. Thus, the reaction of 4 with Mel in the presence of EtONa afforded 4-hydroxy-2methylsulfanyl-6-(4-octadecyloxyphenyl)pyrimidine5-carbonitrile (5) and treatment of 5 with $\mathrm{POCl}_{3} / \mathrm{PCl}_{5}$ on a water bath yields 4-chloro-2-methylsulfanyl-6(4-octadecyloxyphenyl)-pyrimidine-5-carbonitrile (6).

The electron deficient nature of the pyrimidine ring of 6 and the high reactivity of the methylthio group towards nucleophilic reagents facilitated the synthesis of a large number of condensed pyrimidine via nucleophilic aromatic substitutions. Thus, the reaction of 6 with hydrazine hydrate in refluxing $\mathrm{BuOH}$ for $2 \mathrm{~h}$ gave 2,4-dihydrazino-6-(4octadecyloxyphenyl)-pyrimidine-5-carbonitrile (7), which was further cyclized to 6-hydrazino-4-(4octadecyloxyphenyl)-1 H-pyrazolo[3,4-d]pyrimidin3-ylamine (8) by refluxing in $\mathrm{BuOH}$ for $5 \mathrm{~h}$.

The formation of 8 occurs via nucleophilic attack of the hydrazino moiety to the $\mathrm{CN}$ group in ortho position. Treatment of 6 with thiourea in EtOH solution produced 4-mercapto-2-methylsulfanyl-6(4-octadecyloxyphenyl)-pyrimidine-5-carbonitrile (9). Alkylation of 9 with chloroacetic acid in $\mathrm{EtOH}$ solution containing AcONa afforded S-alkylated derivative 10 that was cyclized to thienopyrimidine derivative 11 in $\mathrm{EtOH}$ containing EtONa.

Of particular interest is a cyclocondensation reaction of thienopyrimidine 11 with phenyl isothiocyanate which resulted in the formation of the tricyclic heterocycle 12.

In the present investigation, compound 10 was used to add an aminothiadiazole moiety to the pyrimidine system via the condensation with thiosemicarbazide in presence of $\mathrm{POCl}_{3}$, it underwent ring closure to give aminothiadiazole derivative 13 . Furthermore, the reaction of 9 with $\beta$-benzoylacrylic acid in dry benzene and in the presence of a few drops of piperidine gave 2-[5-cyano-2-methylsulfanyl6-(4-octadecyloxyphenyl)-pyrimidin-4-ylsulfanyl]-4oxo-4-phenyl-butyric acid (14), which was used to construct another heterocyclic nucleus of biological interest. Thus, the reaction of 14 with hydrazine hydrate in boiling EtOH afforded 2-methylsulfanyl-4(4-octadecyloxyphenyl)-6-(3-oxo-6-phenyl-2,3,4,5tetrahydropyridazin-4-ylsulfanyl)-pyrimidine-5carbonitrile (15). Condensation of 14 with hydroxylamine hydrochloride in boiling pyridine yielded 2-methylsulfanyl-4-(4-octadecyloxy-phenyl)6-(6-oxo-3-phenyl-5,6-dihydro-2 $\mathrm{H}$-[1,2] oxazin-5ylsulfanyl)-pyrimidine-5-carbonitrile (16) (Scheme 2).

\subsection{Conversion of the prepared compounds (4- 16) to nonionic surfactants (17a-c to $28 a-c)$}

Propylene oxide condensation is one of the principal processes employed to introduce a hydrophilic functional group into organic compounds. The ultimate objective of the process is the production of surface active agents having the desired hydrophile-lipophile balance for such commercial applications such as detergents, emulsification, wetting and textile processing (Ahmed, 2004). One of the most important groups of surfactants with growing industrial interest is the nonionic, which can be synthesized by propoxylation with the propylene oxide of compounds, which contain $\mathrm{XH}$ groups in the presence of $\mathrm{KOH}$ as a catalyst, as the following equation

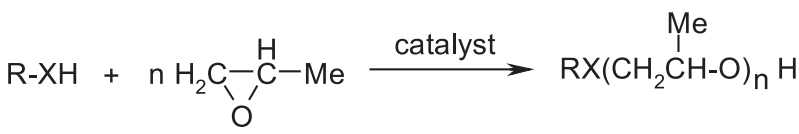

$\mathrm{R}$ is a long chain aliphatic hydrocarbon $\left(\mathrm{C}_{18}\right) ; \mathrm{XH}$ is $\mathrm{OH}, \mathrm{SH}, \mathrm{COOH}, \mathrm{NH}, \mathrm{NH}_{2}$ and $(n)$ the moles of propylene oxide $(\mathrm{n}=5,10,15$ mole) reacted with one mole of starting molecules. The addition of propylene oxide gave nonionic surfactants (17a-c to $28 \mathrm{a}-\mathrm{c})$. The reaction conditions are illustrated in Table 1. Scheme 3 shows the propenoxylation of compounds 4 and 11 as an example.

\subsection{Surface active properties}

Nonionic surfactants find diverse applications, both in industry and in the home. Their moderate foaming and good detergency are employed in a variety of ways in the leather industry, accelerated soaking and liming are improved by the addition of wetting agents (El-Dougdoug and Ahmed, 2004). The study of the surface active properties of the oxypropylated compounds has been done in an aqueous solution ( $1 \mathrm{wt} \%, \mathrm{pH}=7$ ) at $25^{\circ}$. The surface activity and related properties of the synthesized compounds including surface and interfacial tension, cloud point, wetting time, foaming and emulsification properties are given in Table 2.

\subsubsection{Surface and interfacial tension}

The surface and interfacial tension of the prepared compounds are shown in Table 2. It can be observed that the alkyl chain length gives rise to increased hydrophobic interaction between the alkyl chains and also to increased hydrophobic hydration effects that in turn may reduce the surface tension which provide these compounds with pronounced surface activity.

\subsubsection{Cloud point}

A very important factor in making the most efficient use of nonionic surfactants in an aqueous 


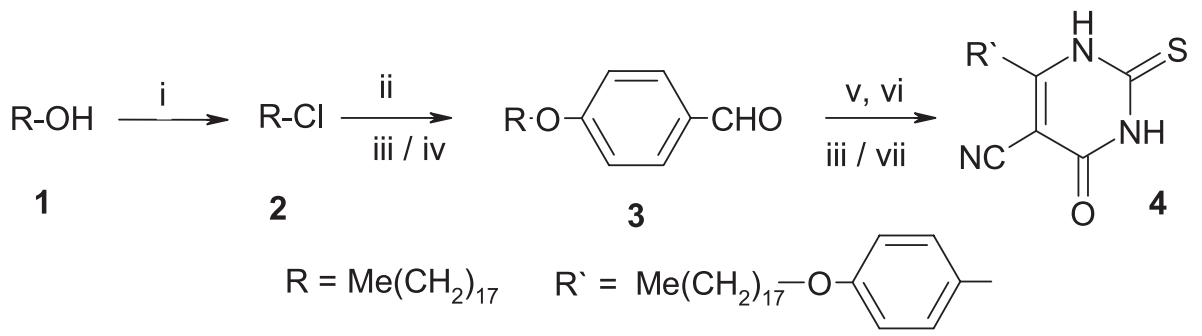

Scheme I

Reagents: (i) $\mathrm{POCl}_{3} / \mathrm{PCl}_{5}$; (ii) $\mathrm{HOC}_{6} \mathrm{H}_{4} \mathrm{CHO}\left(\mathrm{p}\right.$ ); (iii) $\mathrm{K}_{2} \mathrm{CO}_{3}$; (iv) acetone; (v) $\mathrm{NCCH}_{2} \mathrm{COOC}_{2} \mathrm{H}_{5}$; (vi) $\mathrm{NH}_{2} \mathrm{CSNH}_{2}$; (vii) $\mathrm{EtOH}$
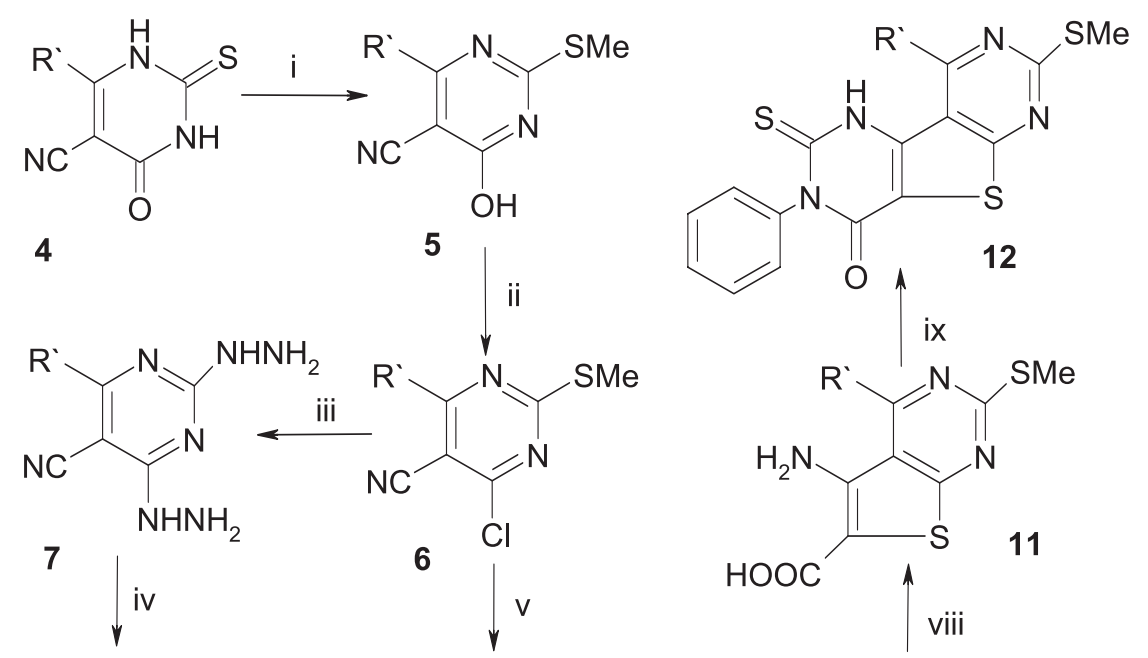<smiles>[R]c1nc(NN)nc2[nH]nc(N)c12</smiles><smiles>[R]c1nc(S(C)(=O)=O)nc(S)c1C#N</smiles><smiles>[R]c1nc(C(C)(C)C)nc(SCC(=O)O)c1C#N</smiles>

8

9<smiles>[Y][V]</smiles><smiles>[R]c1nc(SC)nc(SC2CC(c3ccccc3)=NNC2=O)c1C#N</smiles><smiles>[R]c1nc(S(C)(=O)=O)nc(SC2C=C(c3ccccc3)NOC2=O)c1C#N</smiles><smiles>[Y][Y]</smiles><smiles>[R]c1nc(S(C)(=O)=O)nc(-c2nnc(N)s2)c1C#N</smiles> 
Table 1

Reaction conditions of propenoxylated compounds

\begin{tabular}{|c|c|c|c|c|c|}
\hline Compd & Catalyst, wt \% & Temperature ${ }^{\circ} \mathbf{C}$ & $\begin{array}{l}\text { Propoxylated } \\
\text { product }\end{array}$ & Yield \% & $\begin{array}{c}\text { Degree of } \\
\text { Propenoxylation }{ }^{a} n^{*}\end{array}$ \\
\hline 4 & & & $17 a-c$ & 70 & $5-15$ \\
\hline 6 & & & $18 a-c$ & 72 & $5-15$ \\
\hline 7 & & & $19 a-c$ & 65 & $5-15$ \\
\hline 8 & & & $20 a-c$ & 75 & $5-15$ \\
\hline 9 & & & $21 a-c$ & 70 & $5-15$ \\
\hline 10 & $\mathrm{KOH}, 0.01$ wt $\%$ & $120-125$ & $22 a-c$ & 80 & $5-15$ \\
\hline 11 & & & $23 a-c$ & 72 & $5-15$ \\
\hline 12 & & & $24 a-c$ & 62 & $5-15$ \\
\hline 13 & & & $25 a-c$ & 70 & $5-15$ \\
\hline 14 & & & $26 a-c$ & 73 & $5-15$ \\
\hline 15 & & & $27 a-c$ & 67 & $5-15$ \\
\hline 16 & & & $28 a-c$ & 75 & $5-15$ \\
\hline
\end{tabular}

${ }^{a} n^{*}$ Degree of propenoxylation was calculated by weight.

Table 2

Surface properties of nonionic compounds ${ }^{\text {a }}$

\begin{tabular}{|c|c|c|c|c|c|c|c|c|}
\hline \multirow[t]{2}{*}{ Compd } & \multirow[t]{2}{*}{$n^{b}$} & \multirow{2}{*}{$\begin{array}{c}\text { Surface } \\
\text { Tension } \\
\text { (dyne/cm) } \\
0.1 \%\end{array}$} & \multirow{2}{*}{$\begin{array}{c}\text { Interfacial } \\
\text { Tension } \\
\text { (dyne/cm) } \\
0.1 \%\end{array}$} & \multirow{2}{*}{$\begin{array}{l}\text { Cloud } \\
\text { Point } \\
{ }^{\circ} \mathrm{C} \\
1 \%\end{array}$} & \multirow{2}{*}{$\begin{array}{c}\text { Wetting } \\
\text { time (sec.) } \\
1 \%\end{array}$} & \multirow{2}{*}{$\begin{array}{l}\text { Emulsion } \\
\text { stability } \\
\text { (min.sec) }\end{array}$} & \multicolumn{2}{|c|}{$\begin{array}{c}\text { Foam } \\
\text { power } \\
(\mathrm{mm}) 1 \%\end{array}$} \\
\hline & & & & & & & Intial & $\begin{array}{c}\text { After } 5 \\
\text { min }\end{array}$ \\
\hline $17 a$ & 5 & 27 & 7.5 & 67 & 65 & 260: 40 & 200 & 190 \\
\hline $17 b$ & 10 & 32 & 8.0 & 67 & 90 & 300: 30 & 220 & 205 \\
\hline $17 c$ & 15 & 36 & 8.5 & 91 & 123 & $350: 50$ & 225 & 210 \\
\hline $18 a$ & 5 & 28 & 8.2 & 69 & 90 & $280: 55$ & 155 & 149 \\
\hline $18 b$ & 10 & 32 & 8.7 & 81 & 115 & 320: 25 & 170 & 158 \\
\hline $18 c$ & 15 & 37 & 9.0 & 90 & 132 & $360: 20$ & 190 & 173 \\
\hline $19 a$ & 5 & 26 & 9.5 & 73 & 80 & 250: 10 & 180 & 165 \\
\hline $19 b$ & 10 & 31 & 10.3 & 92 & 110 & 290: 25 & 200 & 189 \\
\hline $19 c$ & 15 & 39 & 11.0 & 99 & 135 & $340: 22$ & 220 & 205 \\
\hline $20 a$ & 5 & 29 & 11.4 & 70 & 100 & 286: 40 & 185 & 163 \\
\hline $20 b$ & 10 & 35 & 12.0 & 87 & 115 & 305: 55 & 200 & 184 \\
\hline $20 c$ & 15 & 37 & 12.5 & 98 & 126 & $330: 30$ & 230 & 210 \\
\hline $21 a$ & 5 & 27 & 6.7 & 63 & 85 & $254: 45$ & 148 & 125 \\
\hline $21 b$ & 10 & 31 & 7.0 & 75 & 100 & 280: 26 & 165 & 136 \\
\hline 21c & 15 & 35 & 7.5 & 96 & 120 & 320: 10 & 188 & 145 \\
\hline $22 a$ & 5 & 25 & 8.7 & 77 & 36 & $227: 21$ & 145 & 124 \\
\hline $22 b$ & 10 & 29 & 9.2 & 90 & 42 & 260: 39 & 159 & 139 \\
\hline $22 c$ & 15 & 35 & 10.0 & 99 & 48 & 300: 38 & 183 & 148 \\
\hline $23 a$ & 5 & 27 & 8.5 & 67 & 30 & $230: 47$ & 210 & 190 \\
\hline $23 b$ & 10 & 32 & 9.0 & 83 & 31 & 270: 50 & 220 & 205 \\
\hline $23 c$ & 15 & 36 & 9.5 & 94 & 36 & 310: 11 & 235 & 214 \\
\hline $24 a$ & 5 & 29 & 7.0 & 59 & 32 & 222: 50 & 190 & 174 \\
\hline $24 b$ & 10 & 33 & 7.5 & 77 & 35 & 265: 11 & 200 & 183 \\
\hline $24 c$ & 15 & 38 & 8.0 & 89 & 35 & $300: 38$ & 205 & 191 \\
\hline $25 a$ & 5 & 28 & 8.6 & 64 & 35 & 226: 17 & 180 & 166 \\
\hline $25 b$ & 10 & 30 & 9.0 & 82 & 40 & 263: 33 & 200 & 182 \\
\hline $25 c$ & 15 & 35 & 9.4 & 93 & 45 & 290: 22 & 210 & 190 \\
\hline $26 a$ & 5 & 27 & 8.7 & 76 & 39 & $227: 21$ & 155 & 128 \\
\hline $26 b$ & 10 & 32 & 9.2 & 86 & 45 & 260: 39 & 160 & 132 \\
\hline $26 c$ & 15 & 36 & 10.0 & 97 & 48 & $300: 38$ & 165 & 146 \\
\hline $27 a$ & 5 & 30 & 7.0 & 73 & 32 & 222: 50 & 190 & 174 \\
\hline $27 b$ & 10 & 36 & 7.5 & 85 & 35 & 265: 11 & 200 & 183 \\
\hline 27c & 15 & 38 & 8.0 & 93 & 35 & 300: 38 & 205 & 191 \\
\hline $28 a$ & 5 & 31 & 8.2 & 70 & 90 & $280: 55$ & 155 & 149 \\
\hline $28 b$ & 10 & 35 & 8.7 & 83 & 115 & $320: 25$ & 170 & 158 \\
\hline $28 c$ & 15 & 37 & 9.0 & 91 & 132 & $360: 20$ & 190 & 173 \\
\hline
\end{tabular}

${ }^{\mathrm{a}}$ Error was: Surface and interfacial tensions $= \pm 0.1 \mathrm{dynes} / \mathrm{cm}$; Cloud point $= \pm 1{ }^{\circ} \mathrm{C}$; foam height $= \pm 2 \mathrm{~mm}$; Wetting time $= \pm 1 \mathrm{sec} ;$ emulsion $= \pm 1 \mathrm{~min}$

${ }^{\mathrm{b}} \mathrm{n}$ in the number of propylene oxide added to the chosen compound. 
<smiles>[R]c1[nH]c(=S)[nH]c(=O)c1C#N</smiles>

4 $x+y=n(5,10,15)$

$\mathrm{a}, \mathrm{n}=5$

b, $n=10$

c, $n=15$<smiles>[R]c1nc(SCC(C)=O)nc2sc(C(=O)O)c(N)c12</smiles><smiles>[R]c1nc(S(C)(=O)=O)nc2sc(C(=O)OCC(C)O[3H])c(N([Y])[14CH3])c12</smiles>

11 $x+y+z=n(5,10,15)$

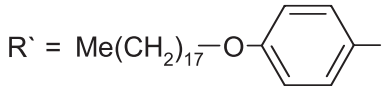

23a-c

Scheme III

system is an understanding of the property called cloud point. All these compounds showed high cloud points which gave performance in hot water and it was increased by increasing the number of the propoxy group.

\subsubsection{Wetting time}

All the prepared compounds showed a decrease in wetting time with an increase in the number of propylene oxide units in the molecule. Moreover, the presence of propylene oxide in different moles caused a reduction in wetting time, i.e. improving their wetting properties which make widely applicable in the textile industry (Somaya et al., 1998).

\subsubsection{Foam properties}

Nonionic surfactants containing an aromatic ring such showed poor foaming properties. The foam height of the prepared surfactants increases with an increase in the number of propylene oxide units per molecule of surfactant. The low foaming power could have an application in the dyeing auxiliary industry (Morgos et al., 1983b).

\subsubsection{Emulsion stability}

Emulsification is one of the most important properties of surfactants. In many textile processes such as scouring and dyeing, it is necessary to introduce surfactants into the bath to remove oily impurities from the fibers. On the other hand, nonionic surfactants with good emulsion stability have been used in such fields as, shampoos, cosmetics, emulsion paints and the textile industry. The results in Table 2 showed that the emulsion stability increases by decreasing the number of propylene oxide units.

\subsection{Biodegradability}

The trend of degradation in river die-away tests was followed by surface tension measurements. The results are given in Table 3 . The rate of degradation of these compounds depends on the size of the molecule; a bulky molecule diffuses through the cell membrane, and its degradation is more difficult. This means that molecules with a low proportion of propylene oxide are more easily degraded than those containing a higher proportion.

\subsection{Biological activity}

All the prepared compounds were screened for their activity against Gram-positive bacteria (Staphyloccus aureus, Bacillus subtilis, Bacillus cereus), Gram-negative bacteria (Pseudomonas aurignosa, Echerichia coli, Enterobacter aerogenes), as well as fungi (Aspergillus niger, Penicillium italicum, Fusarium oxysporum). Also, a comparison between the activity of our synthesized compounds and sulphadiazine as standard drug was discussed. The results are listed in Tables 4 and 5. It is apparent from Table 4 that some of the synthesized compounds showed antibacterial activity.

However, concerning the activity against Grampositive bacteria (Bacillus subtilis), compounds 21c, 26c, 27c and 28c showed excellent activity, 
Table 3

Biodegradability of the prepared surfactants ${ }^{a}$

\begin{tabular}{|c|c|c|c|c|c|c|c|c|}
\hline Compd & $\mathrm{n}^{\mathrm{a}}$. & $1^{\text {st }}$ day & $2^{\text {nd }}$ day & $3^{\text {rd }}$ day & $4^{\text {th }}$ day & $5^{\text {th }}$ day & $6^{\text {th }}$ day & $7^{\text {th }}$ day \\
\hline $17 a$ & 5 & 49 & 62 & 70 & 77 & 86 & 92 & - \\
\hline $17 b$ & 10 & 46 & 56 & 69 & 72 & 83 & 88 & - \\
\hline $17 c$ & 15 & 40 & 51 & 66 & 72 & 79 & 83 & - \\
\hline $18 a$ & 5 & 53 & 65 & 71 & 81 & 93 & - & - \\
\hline $18 b$ & 10 & 48 & 59 & 69 & 77 & 80 & 91 & - \\
\hline $18 c$ & 15 & 45 & 57 & 67 & 74 & 78 & 88 & - \\
\hline $19 a$ & 5 & 55 & 55 & 62 & 79 & 87 & 90 & - \\
\hline $19 b$ & 10 & 49 & 51 & 59 & 67 & 78 & 88 & - \\
\hline $19 c$ & 15 & 47 & 48 & 57 & 63 & 72 & 85 & - \\
\hline $20 a$ & 5 & 53 & 58 & 66 & 80 & 82 & 93 & - \\
\hline $20 b$ & 10 & 50 & 56 & 63 & 71 & 79 & 96 & - \\
\hline $20 c$ & 15 & 49 & 54 & 59 & 68 & 95 & - & - \\
\hline $21 a$ & 5 & 57 & 62 & 71 & 79 & 85 & 93 & - \\
\hline $21 b$ & 10 & 55 & 57 & 69 & 73 & 83 & 90 & - \\
\hline $21 c$ & 15 & 52 & 52 & 68 & 71 & 79 & 87 & - \\
\hline $22 a$ & 5 & 48 & 60 & 68 & 78 & 89 & - & - \\
\hline $22 b$ & 10 & 45 & 56 & 66 & 73 & 76 & 98 & - \\
\hline $22 c$ & 15 & 41 & 51 & 64 & 70 & 73 & 80 & - \\
\hline $23 a$ & 5 & 49 & 66 & 79 & 89 & 96 & - & - \\
\hline $23 b$ & 10 & 48 & 63 & 73 & 86 & 95 & - & - \\
\hline $23 c$ & 15 & 43 & 59 & 71 & 79 & 88 & 96 & - \\
\hline $24 a$ & 5 & 50 & 62 & 68 & 79 & 92 & - & - \\
\hline $24 b$ & 10 & 47 & 55 & 63 & 72 & 80 & 93 & - \\
\hline $24 c$ & 15 & 43 & 49 & 45 & 65 & 77 & 91 & - \\
\hline $25 a$ & 5 & 54 & 54 & 60 & 77 & 80 & 93 & - \\
\hline $25 b$ & 10 & 48 & 52 & 57 & 65 & 76 & 90 & - \\
\hline $25 c$ & 15 & 45 & 49 & 54 & 61 & 73 & 86 & - \\
\hline $26 a$ & 5 & 55 & 63 & 73 & 82 & 78 & 80 & - \\
\hline $26 b$ & 10 & 52 & 59 & 70 & 75 & 85 & 92 & - \\
\hline $26 c$ & 15 & 49 & 54 & 69 & 73 & 81 & 91 & - \\
\hline $27 a$ & 5 & 54 & 63 & 73 & 84 & 95 & - & - \\
\hline $27 b$ & 10 & 48 & 55 & 67 & 79 & 92 & - & - \\
\hline $27 c$ & 15 & 45 & 50 & 61 & 72 & 84 & 93 & - \\
\hline $28 a$ & 5 & 55 & 67 & 75 & 85 & 95 & - & - \\
\hline $28 b$ & 10 & 52 & 59 & 71 & 82 & 92 & - & - \\
\hline $28 \mathrm{c}$ & 15 & 50 & 56 & 61 & 75 & 88 & 93 & - \\
\hline
\end{tabular}

${ }^{a}$ Error of calculations was: Biodegradation rate $= \pm 0.5 \%$.

compounds 22b, 23c, 24c and 25c exhibit good activity, whereas compounds $17 \mathrm{a}, 18 \mathrm{a}, 18 \mathrm{c}$ and $19 \mathrm{c}$ showed moderate activity. On the other hand, the Gram-negative bacteria (Pseudomonas aurignosa) showed high responses to five of the prepared products. Compound $28 \mathrm{c}$ exhibits excellent antibacterial activity towards Entrobacter aerogenes.

Concerning the data of antifungal activity in Table 5, compounds $21 \mathrm{~b}$ and 25b showed excellent activity against Aspergillus niger, while compounds 23b, 24b, 25c and 26c exhibit good activity. Also, compound 28b displays good activity toward Penicillium italicum. In general, the data obtained from the microbiological screening showed that the activity of most of the synthesized compounds showed moderate activity.

\section{CONCLUSION}

It can be concluded that all prepared nonionic surfactants exhibited antibacterial and antifungal properties as well as emulsifier properties. Therefore, their potential use in a non edible media such as insecticides or pesticides as well as in the manufacturing of drugs, cosmetics, antibacterial and/or antifungal is recommended.

\section{ACKNOWLEDGMENTS}

Origin of cultures: Botany Department, Faculty of Science, Benha University, Egypt.

\section{BIBLIOGRAPHY}

Ahmed MHM. 2004. Preparation and surface active properties of novel succinic acid based surfactants. Olaj, Szappan, Kozmetika. 53 (1) 23-26.

Aly AA. 2005. A Convenient synthesis and pharmacological activity of novel annulated pyrimidine derivatives. Chinese. J. Chem. 23 (2) 1-5.

Aly AA, Nassar SA. 2004. N-[4-(dicyanomethylazo) phenyl]-2-saccharin-2-ylacetamide in the synthesis of 
Table 4

Antibacterial activity of the prepared compounds

\begin{tabular}{|c|c|c|c|c|c|c|}
\hline Compd & $\begin{array}{c}\text { Stophyloccus } \\
\text { aureus s }\end{array}$ & $\begin{array}{l}\text { Bacillus } \\
\text { subtilis }\end{array}$ & $\begin{array}{l}\text { Bacillus } \\
\text { cereus }\end{array}$ & $\begin{array}{c}\text { Pseudomonas } \\
\text { aurignosa }\end{array}$ & $\begin{array}{c}\text { Escherichia } \\
\text { coli }\end{array}$ & $\begin{array}{c}\text { Enterobacter } \\
\text { aerogenes }\end{array}$ \\
\hline $17 a$ & + & + & + & + & + & + \\
\hline $17 b$ & + & - & + & + & + & ++ \\
\hline $17 c$ & ++ & - & ++ & ++ & + & ++ \\
\hline $18 a$ & + & + & + & + & + & + \\
\hline $18 b$ & ++ & - & + & + & + & ++ \\
\hline $18 c$ & + & + & + & +++ & + & + \\
\hline $19 a$ & + & + & + & + & + & + \\
\hline $19 b$ & ++ & - & ++ & + & + & ++ \\
\hline $19 c$ & ++ & + & ++ & ++ & + & ++ \\
\hline $20 a$ & + & - & + & ++ & + & ++ \\
\hline $20 b$ & ++ & - & + & + & + & + \\
\hline $20 c$ & ++ & + & + & ++ & + & ++ \\
\hline $21 a$ & + & + & + & + & + & + \\
\hline $21 b$ & + & + & + & + & + & + \\
\hline $21 c$ & ++ & +++ & + & ++ & + & + \\
\hline $22 a$ & ++ & + & ++ & ++ & + & ++ \\
\hline $22 b$ & ++ & ++ & ++ & ++ & + & ++ \\
\hline 22c & ++ & + & ++ & ++ & + & ++ \\
\hline $23 a$ & ++ & + & ++ & +++ & + & ++ \\
\hline $23 b$ & ++ & + & ++ & ++ & + & ++ \\
\hline $23 c$ & ++ & ++ & ++ & ++ & + & ++ \\
\hline $24 a$ & ++ & + & + & ++ & + & ++ \\
\hline $24 b$ & ++ & + & ++ & ++ & + & ++ \\
\hline $24 c$ & ++ & ++ & ++ & +++ & + & ++ \\
\hline $25 a$ & ++ & + & + & ++ & + & ++ \\
\hline $25 b$ & ++ & + & ++ & ++ & + & ++ \\
\hline $25 c$ & ++ & ++ & ++ & ++ & + & ++ \\
\hline $26 a$ & + & + & + & ++ & + & + \\
\hline $26 b$ & ++ & + & ++ & ++ & + & ++ \\
\hline $26 c$ & ++ & +++ & ++ & +++ & + & ++ \\
\hline $27 a$ & + & + & + & + & + & + \\
\hline $27 b$ & ++ & + & ++ & ++ & + & ++ \\
\hline $27 c$ & ++ & +++ & ++ & +++ & + & ++ \\
\hline $28 a$ & + & + & + & + & + & + \\
\hline $28 b$ & ++ & + & ++ & ++ & + & ++ \\
\hline $28 c$ & ++ & +++ & ++ & ++ & + & ++ \\
\hline Sulphadiazine & ++ & ++ & ++ & ++ & ++ & +++ \\
\hline
\end{tabular}

${ }^{\mathrm{a}}$ Error of calculations was: Biodegradation rate $= \pm 0.5 \%$.

pyridazine and pyrimidine derivatives. Heteroatom Chem. 15 (1) 1-4.

Amin MS, Eissa AMF, Shaaban AF, El-Sawy AA, ElSayed R. 2004. New heterocycles having a double characters; as antimicrobial and surface active agents. Part 1: Nonionic compounds from fatty acid isothiocyanate. Grasas Aceites 55 (4) 370-376.

Amin MS, Aly AA, El-Sayed R. 2006. Synthesis and surface active properties of quinazoline derivatives of industrial application. Ind. J. Chem. 45B, 1020.

Chaudlhuri RK, Login RB, Tracy D J. 1987. U.S. Patent. 4, 463-468.

Eissa AMF, El-Sayed R. 2006. Synthesis and evaluation of condensed and noncondensed heterocyclic compounds of industrial application. J. Heterocyclic Chem. 43, 1-9.

Amin MS, Hebash KA, Ahmed MHM, El-Sheikh AA. 2006. New heterocycles having double characters as antimicrobial and as surface active agents. Part 5: New quinazoline derivatives from stearic acid. Olaj, Szappan, Kozmetika 55 (4) 126121

Draves CZ. Clarkso R. 1931., J. Am. Dye Stuff Reporter 20, 201
El-Sayed R, Wasfy AAF, Aly AA. 2005. Synthesis of novel heterocycles with antimicrobial and surface Activity. $J$. Heterocyclic Chem. 42 (1) 1-6.

El-Sayed R. 2006. Synthesis, antibacterial and surface activity of 1,2,4-triazole derivatives. Grasas Aceites. 57 (2) 180-188.

El-Dougdoug WIA, Ahmed MHM. 2004. Synthesis and surface active properties of gawafa fats based amphoteric surfactants. Olaj, Szappan, Kozmetika. 53 (2) 63-68.

El-Sawy AA, Essawy SA, El-Sukkary MM, Eissa AMF. 1992. Surfactants from 2-hydroxy fatty acids. Hungarian Journal of Industerial chemistry. 20, 25.

El-Sukkary MA, El-Sawy AA, El-Dib F. 1987. Synthetic Detergents from Crude rice bran oil. Hungarian Journal of Industrial Chemistry 15, 317-322.

Eman AE, Mohamed AK. 2004. 2-Cyanoacetamide in the synthesis of heterocyclic compounds: Synthesis of new polysubstituted pyrazole, pyridine and pyramimidine derivatives. J. Chinese Chem. Soc. 51, 779-784.

Eter ET, Richard RE, Darid A. 1974. Biodegradable surfactants derived from corn starch. J. Am. Oil Chem. Soc. 51, 486-491. 
Table 5

Antifungal activity of the prepared compounds

\begin{tabular}{|c|c|c|c|}
\hline Compd & $\begin{array}{c}\text { Aspergillus } \\
\text { niger }\end{array}$ & $\begin{array}{c}\text { Penicillium } \\
\text { italicum }\end{array}$ & $\begin{array}{c}\text { Fusarium } \\
\text { oxysporum }\end{array}$ \\
\hline $17 a$ & + & + & + \\
\hline $17 b$ & + & + & ++ \\
\hline $17 c$ & + & + & ++ \\
\hline $18 a$ & + & + & + \\
\hline $18 b$ & + & + & ++ \\
\hline $18 c$ & + & + & ++ \\
\hline $19 a$ & + & + & + \\
\hline $19 b$ & + & + & ++ \\
\hline $19 c$ & + & + & ++ \\
\hline $20 a$ & + & + & + \\
\hline $20 b$ & + & + & ++ \\
\hline $20 c$ & + & + & ++ \\
\hline $21 a$ & + & + & + \\
\hline $21 b$ & +++ & + & ++ \\
\hline $21 c$ & + & + & ++ \\
\hline $22 a$ & + & + & + \\
\hline $22 b$ & + & + & ++ \\
\hline $22 c$ & + & + & ++ \\
\hline $23 a$ & + & + & + \\
\hline $23 b$ & ++ & + & ++ \\
\hline $23 c$ & + & + & ++ \\
\hline $24 a$ & + & + & + \\
\hline $24 b$ & ++ & + & ++ \\
\hline $24 c$ & + & + & ++ \\
\hline $25 a$ & + & + & + \\
\hline $25 b$ & +++ & + & ++ \\
\hline $25 c$ & ++ & + & ++ \\
\hline $26 a$ & + & + & + \\
\hline $26 b$ & + & + & ++ \\
\hline $26 c$ & ++ & + & ++ \\
\hline $27 a$ & + & + & + \\
\hline $27 b$ & + & + & ++ \\
\hline $27 c$ & + & + & ++ \\
\hline $28 a$ & + & + & + \\
\hline $28 b$ & + & ++ & ++ \\
\hline $28 c$ & + & + & ++ \\
\hline Sulphadiazine & ++ & ++ & ++ \\
\hline
\end{tabular}

Findly A. 1963. Practical Physical Chemistry. Longmans, London., 6th Ed.1040.

Gean VS, Ademir N, Evandro LD, César Z. 2001. Preparation of aromatic esters and dioxolanes under microwave irradiation. Synthetic Communications 31, 3323

Maisa IA, Ahmed AG, Galal ME, Soliman MM. 2004. Synthesis of new furo[2,3-d]pyrimidine and pyrimido[4 $\left., 5^{`}: 4,5\right]$ furo[2,3-d]pyrimidines., J. Chinese Chem. Soc. 51, 1357-1366.

Masuyama A, Akiyama K, Okahara M. 1987. Surface active hydroxamic acid. II. Comparison of surface properties of hydroxamic acids with ketones and methyl esters with similar hydrophilic and lipophilic structure. J. Am. Oil. Chem. Soc. 64, 1040-1043.

Morgos J, Sallay P, Farkas L, Rus Znar I. 1983. J. Am. Oil Chem. Soc. 60, 11.

Rosen MJ. 1989. Surfactants and interfacial phenomena. 2th Ed., John Wiley \& Sons, New York, 286-294.

Somaya AR, Eissa AMF, Nadia A, Ahmad MN. 1998. Synthesis and characterization of some peptides having surface activity using polyethylene glycol. $J$. Pharm. Sci. 7, 27.

Takeshi H. 1970. Studies of ester containing surfactant: Preparation and properties of sodium sulphalkanoates. Bull. Chem. Soc. 43, 2236-2239.

Xu LZ, Jian FF, Shi JG, Li L. 2004. Synthesis, structure and biological activities of novel triazole compounds containing 4,6-dimethyl-pyrimidine-2-thio group., J. Chinese Chem. Soc. 22, 1308-1312.

Wanchai P, Warinthorn C. 2006. An efficient method for chlorination of alcohols using $\mathrm{PPh}_{3} / \mathrm{Cl}_{3} \mathrm{CCONH}_{2}$. Tetrahedron Letters 47, 6821

Wiel JK, Smith FD, Stirton AJ, Bistine RG. 1963. Long chain alkanesulphonates and 1-hydroxy-2alkanesulphonates: Structure and property relations. J. Am. Oil. Chem. Soc. 40, 538-542.

Yvette Al, Aly AA. 2003. A convenient synthesis of new pentaazacyclopentanaphthalene and pentaazaphenanthrene derivatives. Z. Naturforsch. 58b, 1227.

Recibido: $14 / 8 / 07$ Aceptado: 24/10/07 